\title{
PEMBELAJARAN KIMIA DENGAN PROBLEM SOLVING MENGGUNAKAN MEDIA E-LEARNING DAN KOMIK DITINJAU DARI KEMAMPUAN BERPIKIR ABSTRAK DAN KREATIVITAS SISWA
}

\author{
Tri Murtiningrum ${ }^{1}$, Ashadi $^{2}$, Sri Mulyani ${ }^{3}$ \\ ${ }^{1}$ Program Studi Pendidikan Sains, Program Pascasarjana, Universitas Sebelas Maret \\ Surakarta, 57126, Indonesia \\ murtiningrum61@yahoo.co.id \\ ${ }^{2}$ Program Studi Pendidikan Sains, Program Pascasarjana, Universitas Sebelas Maret \\ Surakarta, 57126, Indonesia \\ ashadi_uns@yahoo.com \\ ${ }^{3}$ Program Studi Pendidikan Sains, Program Pascasarjana, Universitas Sebelas Maret \\ Surakarta, 57126, Indonesia \\ mulyanis@yahoo.com
}

\begin{abstract}
Abstrak
Inovasi pembelajaran dapat memanfaatkan kemajuan teknologi. e-learning dan komik dapat dijadikan sebagai alternatif media pembelajaran untuk meningkatkan prestasi belajar. Pembelajaran problem solving dengan e-learning dan komik, dapat melatih siswa untuk memecahkan masalah untuk membentuk konsep. Penelitian ini bertujuan untuk mengetahui: pengaruh pembelajaran kimia dengan problem solving menggunakan media $e$-learning dan komik, kemampuan berpikir abstrak, kreativitas siswa dan interaksinya terhadap prestasi belajar ikatan kimia. Populasi dari penelitian ini adalah siswa kelas XI SMK N 2 Purwodadi Grobogan tahun pelajaran 2012/2013. Sampel dipilih secara acak (cluster random sampling), sejumlah 2 kelas, yaitu kelas XI TOKR 3 sebagai kelas e-learning dan XI TOKR 2 sebagai kelas komik. Teknik pengumpulan data menggunakan teknik tes untuk prestasi belajar kognitif, kemampuan berpikir abstrak, dan kreativitas sedangkan prestasi belajar afektif menggunakan angket. Uji hipotesis menggunakan analisis non parametric Kruskal-Wallis Test. Berdasarkan hasil penelitian dapat disimpulkan bahwa: (1) ada pengaruh pembelajaran kimia dengan problem solving menggunakan media e-learning dan komik terhadap prestasi belajar siswa; (2) ada pengaruh kemampuan berpikir abstrak terhadap prestasi belajar siswa; (3) ada pengaruh kreativitas terhadap prestasi belajar siswa; (4) ada interaksi antara pembelajaran kimia dengan problem solving menggunakan media e-learning dan komik dengan kemampuan berpikir abstrak terhadap prestasi belajar siswa; (5) ada interaksi antara pembelajaran kimia dengan problem solving menggunakan media e-learning dan komik dengan kreativitas siswa terhadap prestasi belajar siswa; (6) ada interaksi antara kemampuan berpikir abstrak dengan kreativitas dan terhadap prestasi belajar siswa; (7) ada interaksi antara pembelajaran kimia dengan problem solving menggunakan media e-learning dan komik, kemampuan berpikir abstrak dan kreativitas siswa terhadap prestasi belajar siswa.
\end{abstract}

Kata Kunci: problem solving, e- learning, komik, kemampuan berpikir abstrak, kreativitas.

\section{Pendahuluan}

Salah satu ukuran kemajuan suatu bangsa dapat dilihat dari kualitas pendidikannya. Pendidikan merupakan salah satu bentuk perwujudan kebudayaan manusia yang dinamis dan syarat dengan perkembangan. Seiring dengan kemajuan teknologi, pendidikan pun dituntut perkembangannya sesuai dengan kemajuan teknologi, agar mampu mewujudkan tujuan pendidikan nasional. Salah satu tujuan nasional yang tercantum dalam Pembukaan
Undang-Undang Dasar 1945 adalah untuk mencerdaskan kehidupan bangsa, dan pemerintah berkewajiban menyelenggarakan satu sistem pendidikan nasional.

Berdasarkan Undang-Undang nomor 20 tahun 2003 tentang sistem pendidikan nasional: tujuan pendidikan nasional adalah mencerdaskan kehidupan bangsa dan mengembangkan manusia Indonesia seutuhnya, yaitu manusia yang beriman dan bertakwa terhadap Tuhan Yang 
Maha Esa dan berbudi pekerti luhur, memiliki pengetahuan dan keterampilan kesehatan jasmani dan rohani, kepribadian yang mantap dan mandiri serta rasa tanggung jawab kemasyarakatan dan kebangsaan.

Pendidikan bertujuan untuk meningkatkan kualitas sumber daya manusia sehingga terbentuk manusia yang berkarakter, berbudi luhur, dan berakhlak mulia. Salah satu upaya pemerintah untuk meningkatkan kualitas pendidikan, adalah dengan mengimplementasikan kurikulum tingkat satuan pendidikan (KTSP). Mulyasa (2010: 81) menyatakan bahwa implementasi KTSP menuntut kemandirian guru untuk memberdayakan tenaga kependidikan, sebab keberhasilan pendidikan di sekolah sangat ditentukan oleh keterlibatan tenaga kependidikan dalam seluruh kegiatan di sekolah. Hal ini dimaksudkan bahwa guru dan lingkungan belajar mempunyai peranan sangat penting dalam meningkatkan kualitas pendidikan.

Untuk itu guru dan lingkungan belajar yang kondusif sangat diperlukan. Guru dituntut agar lebih inovatif dan produktif dalam melakukan pembelajaran di kelas sehingga diperoleh hasil belajar yang maksimal. Dalam kurikulum KTSP siswa harus dapat menguasai semua kompetensi secara menyeluruh sehingga menjadi pribadi yang utuh dan bertanggung jawab. Dengan penerapan kurikulum KTSP diharapkan guru mengoptimalkan proses pembelajaran dengan pendekatan pembelajaran yang berpusat pada peserta didik (student centered learning) dengan metode pembelajaran yang inovatif dan konseling secara efektif, sehingga dapat menciptakan siswa yang aktif dan kreatif. Hal ini dimaksudkan agar guru menerapkan metode pembelajaran yang aktif, inovatif, kreatif, efektif, dan menyenangkan. Metode pembelajaran yang melibatkan keterampilan proses antara lain, contextual teaching and learning, inquiry, kooperatif, proyek dan banyak lagi yang masih perlu dikembangkan oleh guru.

Saat ini pembelajaran masih berpusat pada guru (teacher centered learning), guru menjadi sumber belajar utama, siswa hanya dijejali materi, dan siswa kurang aktif dalam pembelajaran. Proses penyampaian informasi bersifat searah, menurut Sanjaya (2010: 97) dalam melaksanakan peranannya sebagai penyampai informasi, guru sering menggunakan metode ceramah sebagai metode utama. Metode ceramah dirasa kurang tepat dilakukan, karena dalam pembelajaran, kurang interaksi antara siswa dengan guru maupun antara siswa dengan siswa, serta kurang berani mengungkapkan pendapat. Dalam pembelajaran ini keterampilan proses, dan pembentukan konsep tidak dikembangkan, sehingga siswa pasif dan kurang termotivasi.

Kimia merupakan mata pelajaran adaptif di Sekolah Menengah Kejuruan (SMK), sehingga cenderung diremehkan atau dianggap tidak penting oleh siswa. Pelajaran adaptif bukanlah pelajaran utama, tetapi hanya merupakan pelajaran yang menunjang pelajaran-pelajaran produktif. Hal ini berakibat masih rendahnya prestasi belajar kimia siswa kelas XI, untuk materi ikatan kimia dalam empat tahun terakhir. Rata-rata siswa yang mencapai nilai ulangan harian di atas kriteria ketuntasan minimal (KKM) dalam empat tahun terakhir hanya $60 \%$ dari jumlah siswa.

Hasil belajar dipengarui oleh faktor eksternal dan internal. Faktor eksternal meliputi guru, metode, media, sarana prasarana, dan lingkungan yang berkaitan dengan pembelajaran. Faktor internal antara lain kecerdasan, bakat, motivasi berprestasi, kemampuan berpikir abstrak, gaya belajar, dan kemampuan berpikir kritis, kreativitas, dan minat dalam pembelajaran kimia.

Kreativitas merupakan kemampuan siswa untuk memunculkan ide-ide baru dan berdaya cipta. Hal ini merupakan potensi yang perlu mendapatkan apresisasi oleh guru melalui penerapan metode dan penggunaan media pembelajaran. Siswa yang kreatif memiliki ciri antara lain keingintahuan yang berlebih, daya kreasi dan imajinasi yang tinggi pula. Sehingga siswa yang kreatif mampu memahami halhal yang bersifat kongkret dan abstrak.

Menurut Piaget intelektual anak mengalami perkembangan dari sensor- 
motorik, praoperasional, operasional kongkret, hingga operasional formal. Siswa SMK sesuai tahapan tersebut berada dalam kondisi operasional formal, yakni siswa telah memiliki kemampuan untuk memikirkan hal yang bersifat abstrak. Dalam mempelajari ikatan kimia, kemampuan berpikir abstrak perlu untuk diperhatikan. Agar siswa mampu memahami materi yang bersifat abstrak penggunaan media pembelajaran yang tepat akan membantu siswa dalam memahami materi. Teknologi dapat dimanfaatkan sebagai media pembelajaran.

Kemajuan ilmu pengetahuan dan teknologi (IPTEK) yang pesat berdampak pada kecepatan siswa untuk mengakses informasi. Dampak positif yang ditimbulkan adalah siswa yang cenderung mulai aktif, kreatif, inovatif, dan bersinergi dalam berpikir serta berani mengungkapkan ide-ide cemerlang. Hal ini merupakan potensi yang pelu diperhatikan para pendidik. Salah satu wujud dari perhatian tersebut adalah dengan menyelenggarakan pembelajaran yang tepat dan penggunaan media yang selaras dengan kemajuan teknologi. Internet merupakan salah satu media yang dekat dengan siswa, siswa dapat dengan mudah mengakses informasi dengan bebas. e-learning merupakan media yang memanfaatkan teknologi internet yang mudah untuk diterapkan.

Kemajuan teknologi juga berdampak negatif, diantaranya adalah pola pikir yang instan yang berdampak pada rendahnya minat baca siswa. Hal ini merupakan tantangan sendiri untuk guru dalam mengolah bahan ajar hingga diminati siswa. Komik yang berisi bahan ajar merupakan media yang menarik bagi siswa. Dengan komik bahan ajar yang semula perlu pemahaman mendalam dan dirasa berat menjadi mudah dinikmati karena dibuat dalam bentuk cerita dan gambar yang sederhana dan menarik. Komik diharapkan mampu menyederhanakan materi kimia yang konsepnya bersifat abstrak.

Chang (2005: 3) mendifinisikan ilmu kimia adalah ilmu yang mempelajari materi dan perubahannya. Zat-zat yang terlibat dalam perubahan kimia yaitu unsur dan senyawa. Untuk mengetahui ciri dari suatu unsur dan senyawa dapat diketahui dari sifat-sifat kimia dan fisis. Sifat kimia adalah sifat yang dapat ditunjukan dengan melalui perubahan kimia sedangkan sifat fisis merupakan sifat yang dapat diamati tanpa mengubah susunan zatnya. Contoh warna, titik leleh, titik didih, kerapatan dan kepolaran. Dalam materi ikatan kimia pada kelas XI di SMK, salah satu karekteristik materinya yaitu sifat fisisnya. Suatu senyawa akan dapat dilihat sifat fisisnya dari kepolaran zat tersebut. Karakteristik materi ikatan kimia lainya adalah beberapa konsepnya besifat abstrak. Pada konsep ikatan yang abstrak memerlukan penalaran yang logis. Karekteristik siswa SMK yang menyenangi hal-hal yang inovatif dan kreatif. Selain itu siswa SMK sangat antusias pada perkembangan teknologi dan lebih menyukai belajar dengan praktik langsung daripada membaca buku. Sehingga untuk kebanyakan siswa akan sulit untuk memahami kosep-konsep yang abstrak.

Winataputra, dkk (2007: 3.41) mengemukakan pendapatnya bahwa anak pada tahap operasi formal telah memiliki kemampuan mengkoordinasikan secara simultan ataupun secara berurutan menggunakan kemampuan kognitifnya, yaitu kapasitas menggunakan hipotesis dan prinsip-prinsip abstrak, seorang remaja akan mampu berpikir hipotetik, yaitu berpikir untuk memecahkan masalah dengan menggunakan hipotesis yang relevan. Siswa SMK masuk dalam tahap operasi formal, yaitu tahap berpikir abstrak.

Untuk memahami pembelajaran yang bersifat abstrak perlu adanya media yang dapat membantu memecahkan masalah yang dihadapi dalam proses belajar. Dengan menyesuaikan karakteristik siswa SMK media yang digunakan harus bersifat inovatif dan visual agar pembelajaran dapat lebih menarik siswa untuk lebih aktif.

Munandar (2009: 9) berpendapat bahwa kemampuan berpikir divergen merupakan indikator dalam kreativitas. Untuk itu dalam memecahkan masalah yang abstrak siswa dituntut untuk berpikir kreatif. Hal ini menunjukkan perlu diperhatikannya kreativitas siswa dalam proses pembelajaran 
untuk materi-materi yang bersifat abstrak seperti ikatan kimia, bentuk molekul, hidrokarbon dan yang sejenis lainnya. Tercapainya tujuan pembelajaran merupakan ukuran kesuksesan sebuah pembelajaran. Keberhasilan ini meliputi proses dan hasil pembelajaran, hasil pembelajaran yang dapat diukur merupakan prestasi belajar siswa.

Dari uraian di atas untuk meningkatkan prestasi belajar kimia perlu digunakan metode pembelajaran dan media yang bervariasi sesuai karakteristik materi dan karakteristik siswa. Dalam hal ini peneliti menerapkan pembelajaran kimia berbasis problem solving menggunakan media e-learning dan media komik ditinjau dari kemampuan berpikir abstrak dan kreativitas untuk materi ikatan kimia.

Dalam penelitian ini didukung oleh teori-teori belajar, antara lain teori kognitif dan konstruktivisme. Teori kognitif timbul karena berbagai pandangan tentang belajar bukan hanya kegiatan terjadinya perubahan prilaku seseorang. Teori belajar kognitif memandang belajar sebagai proses memfungsikan unsur-unsur kognitif. Aktivitas belajar pada diri manusia ditekankan pada proses internal berpikir, yakni proses pengolahan informasi.

Bruner cit. Dahar (2006: 33) menganggap bahwa belajar penemuan sesuai dengan pencarian pengetahuaan secara aktif oleh manusia dan dengan sendirinya memberikan hasil yang paling baik. Siswa yang aktif akan cenderung mencari dan menyelesaikan masalah yang timbul, ini merupakan suatu pengalaman tersendiri bagi siswa untuk menemukan konsep pengetahuan sehingga pembelajaran akan lebih mempunyai makna karena siswa akan lebih paham dan mengerti.

Ausubel cit. Dahar (2006: 95) menerangkan bahwa belajar bermakna merupakan suatu proses dikaitkannya informasi baru pada konsep-konsep yang relevan yang terdapat dalam struktur kognitif seseorang. Ini dimaksudkan cara siswa dapat mengaitkan informasi yang baru mereka dapatkan dengan fakta-fakta yang ada, konsep-konsep yang telah dipelajari dan diingat mereka. Apa yang siswa pelajari dan apa yang mereka ketahui sebelumnya merupakan faktor penting yang mempengaruhi belajar. Dengan mengaitkan konsep yang baru dengan yang lama maka anak akan melakukan proses belajar yang bermakna.

Gagne cit. Aunurrahman (2009 : 47) didalam proses belajar terdapat dua fenomena yaitu meningkatkan keterampilan intelektual sejalan dengan meningkatkanya umur serta latihan yang diperoleh individu dan belajar akan lebih cepat jika strategi kognitif dapat dipakai dalam memecahkan masalah secara lebih efisien. Belajar itu dapat terjadi karena adanya kondisi tertentu untuk memperoleh pengetahuan, ketrampilan, kebiasaan dan tingkah laku, dimulai dari yang mudah ke yang sulit, dan metode pemecahan masalah adalah salah satu metode yang tepat untuk digunakan dalam pembelajaran.

Dalam berpikir anak mengalami perkembangan pola pikir dari tahapan yang berbeda-beda. Suyono (2010: 83) mengungkapkan bahwa, Piaget memandang proses berpikir anak sebagai aktivitas gradual, tahap demi tahap dari fungsi intelektual dari kongkret menuju abstrak.

Dalam menerapkan metode pembelajaran, guru harus memilih metode pembelajaran sesuai dengan karakteristik siswanya. Jadi tiap-tiap kelas bisa dimungkinan menggunakan metode pembelajaran yang berbeda dengan kelas lain. Problem solving merupakan salah satu metode pembelajaran yang bisa digunakan dalam pelajaran kimia. Problem solving dapat diartikan sebagai rangkaian aktivitas pembelajaran yang menekankan kepada proses penyelesaian masalah yang dihadapi secara ilmiah. Metode problem solving (metode pemecahan masalah) bukan hanya sekadar metode mengajar, tetapi juga merupakan suatu metode berpikir, sebab dalam problem solving dapat menggunakan metode-metode lainnya yang dimulai dengan mencari data sampai pada menarik kesimpulan. Metode problem solving merupakan metode yang merangsang berpikir dan menggunakan wawasan tanpa melihat kualitas pendapat yang disampaikan oleh siswa. Seorang guru harus mampu 
membuat siswa untuk mencoba mengeluarkan pendapat dan berdiskusi. Langkah-langkah pembelajaran dengan metode problem solving menurut Dewey cit. Sanjaya (2010 : 217) dijelaskan ada enam langkah, yaitu : 1) merumuskan masalah, yaitu langkah siswa menentukan masalah yang akan dipecahkan; 2) menganalisis masalah, yaitu siswa meninjau masalah secara kritis dari berbagai sudut pandang; 3) merumuskan hipotesis, yaitu langkah siswa merumuskan berbagai kemungkinan pemecahan sesuai dengan pengetahuan yang dimilikinya; 4) mengumpulkan data, yaitu langkah siswa mencari dan menggambarkan informasi yang diperlukan untuk pemecahan masalah; 5) pengujian hipotesis yaitu langkah siswa mengambil atau merumuskan kesimpulan sesuai dengan penerimaan dan penolakan hipotesis yang diajukan, 6) merumuskan rekomendasi pemecahan masalah, yaitu langkah siswa menggambarkan rekomendasi yang dapat dilakukan sesuai rumusan hasil pengujian hipotesis dan rumusan kesimpulan.

Rossi dan Breidle cit. Sanjaya (2010: 43) mengemukakan bahwa media pembelajaran adalah seluruh alat dan bahan yang dapat dipakai untuk mencapai tujuan pendidikan seperti radio, televisi, buku, koran, majalah, dan sebagainya. Media bisa dikatakan sebagai sarana yang sering digunakan untuk menunjang keberhasilan proses belajar.

Daryanto (2010: 168) berpendapat bahwa e-learning adalah sistem pembelajaran yang memanfaatkan media elektronik sebagai alat untuk membantu kegiatan pembelajaran. Media elektronik ini mengarah pada seperangkat alat elektronik yang dijadikan sarana untuk menyampakain pesan materi untuk pembelajaran dari guru terhadap siswa didiknya. Dan media elektronik tersebut biasanya meliputi penggunaan komputer dan internet dalam pembelajaran.

Munadi (2010: 159) menjelaskan bahwa istilah e-learning dapat diartikan sebagai jenis belajar mengajar yang memungkinkan tersampaikanya bahan ajar kesiswa dengan menggunakan media internet atau media jaringan komputer lainya. Dalam perkembangan teknologi komunikasi dewasa ini, dunia pendidikan harus mampu memanfaatkannya untuk kemajuan pembelajaran. E-learning merupakan salah satu bentuk kemajuan teknologi yang bisa dijadikan alternatif media pembelajaran.

Daryanto (2010 : 127) menjelaskan tentang komik dapat didefinisikan sebagai bentuk kartun yang mengungkapkan karakter dan menerapkan suatu cerita dalam urutan yang erat hubunganya dengan gambar dan dirancang memberikan hiburan kepada pembaca. Komik juga sering disebut sebagai cerita bergambar yang banyak menarik untuk dibaca. Gambar yang disajikan berupa karakter kartun unik dan menarik sehingga bisa memikat pembacanya.

Sifat pesan singkat, sederhana dan mudah dipahami ini sangat tepat bila digunakan sebagai media belajar untuk anak sekolah, yang rentang usianya antara anakanak dan remaja. Sebagian besar dari mereka menggemari bacaan komik. Jadi sangatlah sesuai jika media pembelajaran di kelas menggunakan bacaan komik yang mengemas materi pembelajaran di kelas. Hal bisa dimanfaatkan guru untuk memberikan bacaan yang bermuatan pendidikan. Dalam hal ini guru harus lebih berkreasi untuk menciptakan suasana belajar yang menarik siswa, dengan memasukan materi yang akan diajarkan kedalam komik.

Jacobsen (2009: 97) berpendapat bahwa abstraksi adalah gagasan yang digunakan manusia untuk menggambarkan, memahami, dan menyederhanakan dunia. Dalam memahami beberapa hal yang belum jelas atau sulit digambarkan secara nyata objek tersebut memerlukan pola-pola mental ataupun konsep pemikiran yang abstrak.

Terman cit. Winkel (2009: 155) menyatakan bahwa inteligensi adalah kemampuan untuk berpikir abstrak. Kemampuan berpikir untuk menggambarkan keteraturan pola-pola dalam dunia yang mampu berpikir menggunakan penalaran dan hipotesis. Sedangkan menurut Winataputra, dkk (2007: 3.37) hasil perkembangan intelektual adalah 
kemampuan berpikir operasional formal. Tahap operasional formal ini bisa dikatakan anak mampu berpikir abstrak dan terjadi pada usia anak beranjak remaja.

Kreativitas siswa perlu ditumbuhkan seperti pendapat Guilford cit. Munandar (2009: 31) yang menyatakan bahwa kreativitas atau berpikir kreatif sebagai kemampuan untuk melihat bermacammacam kemungkinan penyelesaian terhadap suatu masalah, merupakan bentuk pemikiran yang kurang mendapat perhatian. Kreativitas merupakan kemampuan bepikir divergen, yaitu berpikir dengan mengunakan berbagai alternatif jawaban tidak hanya menggunakan satu jawaban tertentu saja. Sehingga dengan mengembangkan kreativitas siswa akan membantu siswa itu sendiri untuk memberikan berbagai alternatif terhadap masalah pembelajaran yang dihadapi.

\section{Metode Penelitian}

Penelitian ini dilaksanaan di SMK negeri 2 Purwodadi, dikelas XI tahun pelajaran 2012/2013. Populasi penelitian ini adalah peserta didik kelas XI Teknik Otomotif Kendaraan Ringan SMK N 2 Purwodadi. Sampel yang digunakan diambil secara acak dari sekelompok kecil yang mewakili populasi.

Adapun jenis instrumen yang dipilih dalam penelitian ini ada dua yaitu instrumen pelaksanaan penelitian dan instrumen pengambilan data. Instrumen pelaksanaan pembelajaran adalah instrumen yang digunakan dalam proses pembelajaran. Instrumen ini meliputi: silabus, rencana pelaksanaan pembelajaran (RPP), media pembelajaran, lembar kerja siswa (LKS). Data penelitian yang diambil dari data langsung yang dilaksanakan sebelum perlakuan dan setelah perlakuan,dengan teknik tes dan nontes.

Tes adalah suatu alat pengukur yang berupa serangkaian pertanyaan yang harus dijawab secara sengaja dalam situasi yang distandarisasikan,dan yang dimaksudkan untuk mengukur kemampuan dan hasil belajar individu atau kelompok. Dalam penelitian ini digunakan tes prestasi, kemampuan berpikir abastrak dan kreativitas dengan menggunakan soal-soal pilihan ganda. Tes prestasi untuk mengukur kemampuan siswa dalam memahami materi pembelajaran, sedangkan tes kemampuan berpikir abstrak dimaksudkan sebagai pengukur kemampuan siswa dapat memahami materi-materi kimia yang bersifat abstrak.

Teknik non tes merupakan alat pengukur nontes berupa rangkaian pertanyaan atau pernyataan yang harus dijawab secara sengaja dalam situasi yang kurang distandarisasikan dan yang dimaksudkan untuk mengukur kemampuan atau hasil belajar yang dapat diamati secara kongkret dari individu atau kelompok. Untuk mengukur kemampuan prestasi belajar ranah afektif digunakan angket.

\section{Hasil Penelitian dan Pembahasan}

Data kemampuan berpikir abstrak siswa dapat diperoleh dari data tes tertulis kemampuan berpikir abstrak,

yang dibagi dalam dua kategori yaitu tinggi dan rendah.

Deskripsi data jumlah siswa berdasarkan kemampuan berpikir abstrak ditunjukkan dalam Tabel 1.

Tabel 1 Deskripsi Jumlah Siswa Ditinjau dari Kemampuan berpikir abstrak Siswa

\begin{tabular}{cccc}
\hline \multirow{2}{*}{ Kelas } & \multirow{2}{*}{$\begin{array}{c}\text { Jumlah } \\
\text { siswa }\end{array}$} & \multicolumn{2}{c}{ Kategori } \\
\cline { 3 - 4 } $\begin{array}{c}E- \\
\text { learning }\end{array}$ & 38 & 16 & 22 \\
\hline Komik & 39 & 19 & 20 \\
\hline Jumlah & 77 & 35 & 42 \\
\hline
\end{tabular}

Kreativitas siswa dikategorikan dalam 2 kelompok yaitu kreativitas tinggi dan kreativitas rendah. Rincian data jumlah siswa ditinjau dari kreativitas siswa dalam Tabel 2.

Tabel 2 Deskripsi Jumlah Siswa Ditinjau dari Kreativitas Siswa

\begin{tabular}{|c|c|c|c|c|}
\hline \multirow[t]{2}{*}{ Kelas } & \multirow{2}{*}{$\begin{array}{l}\text { Jumlah } \\
\text { siswa }\end{array}$} & \multirow{2}{*}{$\begin{array}{c}\text { Rata-rata } \\
\text { Skor } \\
\text { Perolehan }\end{array}$} & \multicolumn{2}{|c|}{$\begin{array}{c}\text { Kategori } \\
\text { Kreativitas }\end{array}$} \\
\hline & & & Tinggi & Rendah \\
\hline E-learning & 38 & \multirow{3}{*}{61} & 17 & 21 \\
\hline Komik & 39 & & 19 & 20 \\
\hline Jumlah & 77 & & 36 & 41 \\
\hline
\end{tabular}


JURNAL INKUIRI

ISSN: 2252-7893, Vol 2, No 32013 (hal 288-301)

http://jurnal.fkip.uns.ac.id/index.php/sains

Deskripsi data jumlah siswa ditinjau dari kelas dengan media e-learning dan komik, kemampuan berpikir abstrak tinggi dan rendah serta kreativitas tinggi dan rendah disajikan dalam Tabel 3.

Tabel 3. Deskripsi Jumlah Siswa Ditinjau dari Metode, Kemampuan berpikir abstrak, dan Kreativitas Siswa

\begin{tabular}{|c|c|c|c|c|}
\hline & & & \multicolumn{2}{|c|}{$\begin{array}{l}\text { Pembelajaran } \\
\text { Berbasis Problem } \\
\text { Solving dengan } \\
\text { Menggunakan Media }\end{array}$} \\
\hline & & & $e$-learning & Komik \\
\hline \multirow{4}{*}{$\begin{array}{l}\text { Kemam- } \\
\text { puan } \\
\text { berpikir } \\
\text { abstrak }\end{array}$} & \multirow{2}{*}{ Tinggi } & $\begin{array}{l}\text { Kreativitas } \\
\text { Tinggi }\end{array}$ & 11 & 13 \\
\hline & & $\begin{array}{l}\text { Kreativitas } \\
\text { Rendah }\end{array}$ & 6 & 6 \\
\hline & \multirow{2}{*}{ Rendah } & $\begin{array}{l}\text { Kreativitas } \\
\text { Tinggi }\end{array}$ & 7 & 6 \\
\hline & & $\begin{array}{l}\text { Kreativitas } \\
\text { Rendah }\end{array}$ & 15 & 14 \\
\hline
\end{tabular}

Hasil uji normalitas pada prestasi belajar ranah kognitif disajikan pada Tabel 4.

Tabel 4. Ringkasan Hasil Uji Normalitas Prestasi Belajar Ranah Kognitif

\begin{tabular}{lcccc}
\hline \multirow{2}{*}{ Kelompok } & \multicolumn{4}{c}{ Kognitif } \\
\cline { 2 - 5 } & $\begin{array}{c}\text { Komolgorov } \\
\text { Smirnov }\end{array}$ & $\begin{array}{c}\text { Taraf } \\
\text { Signifikansi }\end{array}$ & $\begin{array}{c}\text { Keputusan } \\
\text { Uji }\end{array}$ \\
\hline \multirow{2}{*}{ Media } & $\begin{array}{c}\text { E- } \\
\text { learning }\end{array}$ & 0,02 & 0,05 & tidak normal \\
\cline { 2 - 5 } & Komik & 0,04 & 0,05 & tidak normal \\
\hline $\begin{array}{l}\text { Kemampuan } \\
\text { berpikir } \\
\text { abstrak }\end{array}$ & Tinggi & 0,13 & 0,05 & Normal \\
\cline { 2 - 5 } & Rendah & 0,00 & 0,05 & tidak normal \\
\hline \multirow{2}{*}{ Kreativitas } & Tinggi & 0,66 & 0,05 & Normal \\
\cline { 2 - 5 } & Rendah & 0,01 & 0,05 & tidak normal \\
\hline
\end{tabular}

Hasil uji normalitas tiap kelompok untuk prestasi belajar ranah afektif dengan uji Komolgorov-Smirnov disajikan pada Tabel 5.

Tabel 5 Ringkasan Hasil Uji Normalitas Prestasi Belajar Ranah Afektif

\begin{tabular}{lcccc}
\hline \multirow{2}{*}{ Kelompok } & \multicolumn{3}{c}{ Afektif } \\
\cline { 2 - 5 } & $\begin{array}{c}\text { Komolgorov } \\
\text { Smirnov }\end{array}$ & $\begin{array}{c}\text { Taraf } \\
\text { Signifikansi }\end{array}$ & $\begin{array}{c}\text { Keputusan } \\
\text { Uji }\end{array}$ \\
\hline \multirow{2}{*}{ Media } & $\begin{array}{l}\text { E- } \\
\text { learning }\end{array}$ & $0,200^{*}$ & 0,05 & Normal \\
\cline { 2 - 5 } & Komik & $0,200^{*}$ & 0,05 & Normal \\
\hline $\begin{array}{l}\text { Kemampuan } \\
\text { berpikir } \\
\text { bbstrak }\end{array}$ & Tinggi & 0,173 & 0,05 & Normal \\
\cline { 2 - 5 } & Rendah & $0,200^{*}$ & 0,05 & Normal \\
\hline Kreativitas & Tinggi & 0,026 & 0,05 & $\begin{array}{c}\text { tidak } \\
\text { normal }\end{array}$ \\
\cline { 2 - 5 } & Rendah & $0,200^{*}$ & 0,05 & Normal \\
\hline
\end{tabular}

Ringkasan hasil uji homogenitas untuk prestasi kognitif dan afektif disajikan dalam Tabel 6.

Tabel 6 Ringkasan Hasil Uji Homogenitas

\begin{tabular}{lccccc}
\hline \multirow{2}{*}{ Variabel } & \multirow{2}{*}{$\begin{array}{c}\text { Signifi } \\
\text {-kansi }\end{array}$} & \multicolumn{2}{c}{ Kognitif } & \multicolumn{2}{c}{ Afektif } \\
\cline { 3 - 6 } & & $\begin{array}{c}\text { Levene's } \\
\text { test }\end{array}$ & $\begin{array}{c}\text { Keputusan } \\
\text { Uji }\end{array}$ & $\begin{array}{c}\text { Levene's } \\
\text { Test }\end{array}$ & $\begin{array}{c}\text { Keputusan } \\
\text { Uji }\end{array}$ \\
\hline Media & 0,05 & 0,049 & tidak homogen & 0,236 & Homogen \\
\hline $\begin{array}{l}\text { Kemampuan } \\
\text { berpikir } \\
\text { abstrak }\end{array}$ & 0,05 & 0,338 & Homegen & 0,568 & Homogen \\
\hline Kreativitas & 0,05 & 0,269 & Homogen & 0,382 & Homogen \\
\hline
\end{tabular}

Dari Tabel 6 terlihat bahwa hasil uji homogenitas ditinjau dari media dan kreativitas menunjukkan bahwa sampel berasal dari populasi yang memiliki variansi yang tidak homogen untuk ranah kognitif.

Hasil uji non parametrik Kruskal Wallis untuk prestasi belajar kognitif dan afektif disajikan dalam Tabel 7 dan Tabel 8.

Tabel 7 Ringkasan Hasil Uji Non Parametrik Prestasi Belajar Siswa Ranah Kognitif

\begin{tabular}{cccc}
\hline Hipotesis & Signifikansi & $\begin{array}{c}\text { Taraf } \\
\text { Signifikansi }\end{array}$ & $\begin{array}{c}\text { Keputusan } \\
\text { Uji }\end{array}$ \\
\hline 1 & 0,02 & 0,05 & $\mathrm{H}_{0}$ ditolak \\
2 & 0,01 & 0,05 & $\mathrm{H}_{0}$ ditolak \\
3 & 0,00 & 0,05 & $\mathrm{H}_{0}$ ditolak \\
4 & 0,00 & 0,05 & $\mathrm{H}_{0}$ ditolak \\
5 & 0,00 & 0,05 & $\mathrm{H}_{0}$ ditolak \\
6 & 0,00 & 0,05 & $\mathrm{H}_{0}$ ditolak \\
7 & 0,00 & 0,05 & $\mathrm{H}_{0}$ ditolak \\
\hline
\end{tabular}

Tabel 8 Ringkasan Hasil Uji Non Parametrik Prestasi Belajar Siswa Ranah Afektif

\begin{tabular}{cccc}
\hline Hipotesis & Signifikansi & $\begin{array}{c}\text { Taraf } \\
\text { Signifikansi }\end{array}$ & $\begin{array}{c}\text { Keputusan } \\
\text { Uji }\end{array}$ \\
\hline 1 & 0,22 & 0,05 & $\mathrm{H}_{0}$ diterima \\
2 & 0,42 & 0,05 & $\mathrm{H}_{0}$ diterima \\
3 & 0,76 & 0,05 & $\mathrm{H}_{0}$ diterima \\
4 & 0,56 & 0,05 & $\mathrm{H}_{0}$ diterima \\
5 & 0,27 & 0,05 & $\mathrm{H}_{0}$ diterima \\
6 & 0,41 & 0,05 & $\mathrm{H}_{0}$ diterima \\
7 & 0,25 & 0,05 & $\mathrm{H}_{0}$ diterima \\
\hline
\end{tabular}

Pengaruh pembelajaran kimia berbasis problem solving menggunakan e-learning dan komik terhadap prestasi belajar siswa.

Berdasarkan hasil uji non parametrik Kruskal Wallis dapat diketahui bahwa ada pengaruh yang signifikan 
pembelajaran kimia berbasis problem solving menggunakan e-learning dan komik terhadap prestasi belajar siswa. Dalam penelitian ini pembelajaran problem solving menggunakan media e-learning dan komik sama-sama melibatkan siswa secara aktif dalam pembelajaran. Dengan pembelajaran problem solving siswa menggukan pola pikir yang terstruktur dan sistematik untuk dapat menyelesaikan masalah secara bertahap. Penggunaan media dalam pembelajaran problem solving sangat berperan bagi siswa dalam pemecahan masalah.

Menurut Yacob, dkk (2011) strategi pembelajaran dengan e-learning akan menjadi salah satu cara terbaik bagi peserta didik untuk memahami teknologi baru dan mempelajari berbagai konsep, sehingga mereka akan tertarik untuk memahami dan mencari pengetahuan baru. Media $e$ learning mampu menarik perhatian siswa selama pembelajaran berlangsung. Dengan e-learning siswa mampu mengkaitkan media yang digunakan dengan materi pembelajaran. Selain itu e-learning bisa membuka wawasan siswa untuk lebih mengembangkan materi dengan menggunakan kemajuan teknologi. Animasi yang ditampilkan dalam e-learning bisa membuat siswa antusias untuk memperhatikan dengan sungguh-sungguh selama kegiatan belajar berlangsung, elearning dengan sajian materi yang dikemas dalam media visual, mampu membuat siswa fokus memperhatikan dan asik mengikuti alur-alur secara runtut untuk mempelajari materi, ini beda dengan pembelajaran biasa tanpa menggunakan media pembelajaran. Begitu pula dengan pembelajaran problem solving dengan komik, komik mampu menghubungkan konsep yang dipelajari bahasa komik yang sederhana. Talatovic (2009) menyatakan bahwa komik adalah sebuah bentuk seni populer terutama dikalangan anak-anak dan dapat dijadikan sebagai media yang berpotensial untuk pendidikan sains dan komunikasi. Berdasarkan dari hasil penelitianya komik merupakan bacaan yang digemari anakanak, ilmu pengetahuan yang disajikan dalam bentuk komik dan gambar yang menarik siswa hingga dapat meningkatkan prestasi belajar sains. Hal ini menunjukan bahwa komik dapat digunakan sebagai media untuk menjelaskan ilmu pengetahuan. Komik menarik simpati siswa untuk terus membaca materi sehingga sedikit demi sedikit siswa dapat mencerna pelajaran.

Burner cit. Winaputra, dkk (2007: 3.16) mengungkapkan agar pembelajaran dapat mengembangkan ketrampilan intelektual anak maka materi pelajaran perlu disajikan dengan memperhatikan tahap perkembangan kognitif anak yang meliputi tahap enaktif, ikonik, dan simbolik. Penggunaan media komik dalam pembelajaran problem solving ini merupakan penyajian secara ikonik, yaitu pembelajaran yang dilakukan dengan menggunakan media dengan serangkaian gambar-gambar untuk menjelaskan suatu konsep. Dalam penelitian ini pembelajaran problem solving dengan e-learning dan komik ini ternyata komik dapat meningkatkan presatsi belajar siswa lebih baik dibandingkan dengan menggunakan e-learning. Penyajian e-learning dan komik merupakan penggunaa media secara visual. e-learning yang disajikan dalam penelitian ini adalah media visual yang berupa gambar bergerak sehingga anak kurang mampu mengingat dengan jelas, karena anak akan lebih tertarik untuk melihat sajian berikutnya dibanding mencermati gambar yang ada. Sedangkan penggunaan komik merupakan gambar diam yang memberi nilai lebih untuk anak fokus dan mengingat konsep, sehingga ini lebih baik dibandingkan penggunaan elearning, walaupun dalam proses belajar mereka bisa membukanya secara berulangulang.

Andersen cit. Diknas menyatakan bahwa karakteristik siswa meliputi cara yang tipikal dari berpikir, berbuat dan perasaan. Ranah afektif mencakup perilaku seperti perasaan, minat, sikap, emosi, atau nilai. Perilaku seseorang merupakan fungsi dari watak dan karakteristik lingkungan saat perilaku atau perbuatan ditampilkan. Jadi tindakan atau perbuatan siswa dipengaruhi oleh faktor internal (dalam diri siswa) ataupun eksternal (lingkungan). Perubahan 
perilaku afektif tidak berlangsung dengan serta merta tetapi melalui proses yang membutuhkan waktu lebih lama dari pada aspek kognitif dan dukungan dari lingkungan. Dalam penelitian ini diterimanya hipotesis nol $\left(\mathrm{H}_{0}\right)$ untuk semua hipotesis ranah afektif dikarenakan penelitian hanya dilakukan pada satu kompetensi dasar yang tidak didukung dengan pengembangan strategi pembelajaran yang mengacu pada keterampilan proses untuk mata pelajaran lain selain kimia. Kurang seriusnya siswa dalam proses belajar dan tidak adanya dukungan lingkungan mengakibatkan kurang terlihatnya dampak pebelajaran problem solving dengan e-learning dan komik terhadap prestasi belajar siswa ranah afektif.

\section{Pengaruh kemampuan berpikir abstrak terhadap prestasi belajar siswa.}

Dari hasil penelitian diperoleh ada pengaruh yang signifikan kemampuan berpikir abstrak terhadap prestasi belajar siswa baik ranah kognitif sedangkan ranah afektif untuk materi ikatan kimia tidak ada pengaruh yang signifikan. Anak dikatakan masuk pada tingkat operasional formal adalah pada saat kira-kira memasuki usia 11 tahun, seperti yang diungkapkan Piaget. Siswa SMK kelas XI adalah termasuk dalam tahap operasional formal. Dalam tingkatan ini anak sudah menggunakan operasi-operasi kongkretnya untuk membentuk operasioperasi yang lebih kompleks. Hasil akhir yang dapat dicapai pada tahapan ini bahwa anak mampu berpikir abstrak. Sehingga anak sudah dapat berpikir secara efektif dan sistematis, secara proporsional, serta menarik generalisasi secara mendasar seperti yang di ungkapkan Suyono (2010: 85).

Dalam pembelajaran ikatan kimia materi yang diberikan sifatnya abstrak, sehingga siswa perlu memusatkan perhatian yang lebih dalam agar dapat mengerti dan paham akan materi ikatan kimia. Saat proses pembelajaran siswa yang berpikir abstrak tinggi cenderung akan mudah memahami dibanding siswa yang berpikir abstrak rendah. Karena siswa yang berpikir abstrak tinggi akan berusaha merumuskan banyak alternatif hepotesis dalam menanggapi masalah dan mengecek data terhadap setiap hepotesis untuk membuat keputusan yang layak. Selain itu siswa tidak dibatasi pada benda-benda atau peristiwa-peristiwa yang kongkret saja, tetapi mampu menangani proposi yang berlawanan dengan fakta. Ini berbeda dengan siswa yang berpikir abstrak rendah. Hal ini yang menyebabkan adanya perbedaan terhadap prestasi belajar siswa yang mempunyai kemampuan berpikir abstrak tinggi atau rendah terhadap prestasi belajar siswa.

\section{Pengaruh kreativitas terhadap prestasi belajar siswa.}

Perhitungan untuk hipotesis ketiga menunjukkan ada pengaruh yang signifikan kreativitas terhadap prestasi belajar siswa ranah kognitif, tetapi tidak ada pengaruh kreativitas terhadap prestasi belajar siswa ranah afektif. Tingkat kreativitas antara masing-masing siswa tidaklah sama. Karena pengembangan kreativitas dapat diperoleh dari masing-masing pengetahuan yang dimiliki siswa, bisa pula dipengaruhi oleh lingkungan dan segala permasalahanya sehingga menumbuhkan daya kreativitas. Dengan demikian kreativitas yang dimiliki masing- masing siswa berbeda-beda pula.

Dalam pembelajaran ikatan kimia siswa yang aktif dan mempunyai rasa keingintahuan yang besar tergolong siswa yang memiliki kreativitas tinggi. Siswa yang mempunyai kreativitas tinggi selalu ingin mencari pengalaman yang baru, dan tidak merasa puas dengan jawaban yang ada. Mereka akan selalu mencari alternatif untuk mendapatkan solusi lain yang dapat memecahkan masalah.

Selain itu siswa dengan daya kreativitasnya tinggi akan senang mengajukan pertanyaan-pertanyaan dan termotivasi untuk mencari pengalaman baru serta penemuan yang memuasakan bagi mereka. Munculnya kreativitas biasanya didasari oleh pengalaman dan pengetahuan sebelumnya dan dapat berkembang menurut pengalaman atau proses belajar dari siswa tersebut. Dengan demikian siswa yang kreativitasnya tinggi akan memahami materi dengan caranya sendiri sehingga dapat 
mengoptimalkan proses belajarnya dan mengakibatkan prestasi belajarnya meningkat. Sebaliknya siswa yang kreativiasnya rendah akan cenderung pasif dan tidak ada inovasi sehingga dalam memahami materi tidaklah maksimal, siswa tidak antusias dalam menyaelesaikan masalah. Ini berdampak pada prestasi siswa, karena materi ikatan kimia yang tidak mereka pahami, sehingga hasil prestasi belajarnya rendah. Hal yang demikian tersebut yang mengakibatkan siswa yang kreativitasnya tinggi mempunyai prestasi belajar lebih baik dibanding siswa yang kreativitasnya rendah. Maka ada pengaruh yang signifikan antara siswa yang kreativitasnya tinggi dan siswa yang kreativitasnya rendah.

Interaksi antara pembelajaran kimia berbasis problem solving menggunakan $e$ learning dan komik dengan kemampuan berpikir abstrak terhadap prestasi belajar siswa.

Ada interaksi yang signifikan antara metode pembelajaran problem solving menggunakan e-learning dan komik, berarti siswa dengan kemampuan berpikir abstrak tinggi dan rendah diberi perlakukan pembelajaran problem solving dengan $e$ learning maupun komik memberikan prestasi belajar yang berbeda secara signifikan. Hal ini berarti bahwa siswa dengan kemampuan berpikir abstrak tinggi dan rendah jika dalam pembelajaran menggunakan metode dan media yang sesuai akan mempengaruhi prestasi belajar siswa.

Dalam pembelajaran problem solving, siswa dihadapkan pada masalahmasalah yang harus dapat dipecahkan sendiri dalam menguasai materi ikatan kimia. Penggunaan media yang tepat memudahkan guru dalam menyampaikan pesan materi pelajaran ke siswa. Dalam hal ini pembelajaran problem solving dengan menggunakan dua media yang berbeda akan menunjukan tingkat kemampuan berpikir abstrak yang berbeda pula pada siswa.

Penggunaan media e-learning ini mampu memikat simpati siswa. Siswa berperan aktif tanpa merasa dikendalikan oleh guru. Mereka akan sibuk mengikuti tayangan yang ada dalam komputer masingmasing dan mendiskusikan dengan kelompoknya. Agar dalam pemecahan masalahnya memperoleh hasil yang maksimal, siswa dituntut sabar karena harus mengulang-ulang tayangan yang ada. Seperti yang diungkapkan Jacobsen (2009: 252) bahwa teknologi dapat digunakan untuk mengemukakan masalah-masalah yang realistis kepada siswa melalui simulasi-simulasi, yang memungkinkan siswa berpatisipasi secara langsung dalam aktivitas-aktivitas yang benar-benar membangkitkan semangat. Dengan pembelajaran e-learning siswa mulai menghubungkan tampilan media dengan konsep materi ikatan kimia, disini kemampuan berpikir abstrak siswa akan berperan untuk menyelesaikan masalah. Dalam penelitian ini siswa yang mempunyai kemampuan berpikir abstrak rendah akan lebih baik bila pembelajarannya menggunakan e-learning dibanding komik, sehingga berpengaruh pada kenaikan prestasi belajarnya.

Sedangkan pembelajaran problem solving dengan komik siswa juga akan diberikan media yang berupa visualisasi. Komik menyajikan materi yang dilengkapi dengan gambar yang akan membantu siswa dalam memahami materi ikatan kimia. Siswa akan menikmati bacaan seakan mereka tidak sedang dalam kelas yang harus diceramahi guru, melainkan seperti membaca di tempat lain untuk belajar mandiri. Maka siswa dengan sendirinya akan aktif berdiskusi menyelesaikan masalah yang ada guna memahami materi. Komik merupakan media visual sama seperti e-learning, namun komik merupakan gambar diam, sehingga anak lebih mudah untuk mencermatinya. Dengan keluasan proses belajar di penelitian ini siswa yang memiliki kemampuan berpikir abstrak tinggi lebih dapat meningkatkan prestasi belajarnya bila menggunakan media komik dibanding e-learning. Dengan demikian ada interaksi antara pembelajaran problem solving menggunakan e-learning dan komik dengan kemampuan berpikir abstrak siswa terhadap prestasi belajar. 
Interaksi antara pembelajaran kimia berbasis problem solving menggunakan $e$ learning dan komik dengan kreativitas terhadap prestasi belajar siswa.

Dari hasil uji statistik dapat dilihat ada interaksi yang signifikan antara pembelajaran kimia berbasis problem solving menggunakan e-learning dan komik dengan kreativitas terhadap prestasi belajar siswa ranah kognitif, tetapi tidak ada interaksi yang signifikan antara pembelajaran kimia berbasis problem solving menggunakan e-learning dan komik dengan kreativitas terhadap prestasi belajar siswa ranah afektif.

Dalam era perkembangan IPTEK yang begitu pesat dewasa ini, profesionalisme guru tidak cukup hanya dengan membelajakan siswa, tetapi harus mampu mengelola informasi dan lingkungan untuk memfasilitasi kegiatan belajar siswa. Yacob, dkk (2011). Melakukan penelitian tentang kesadaran siswa dalam penggunaan e-learning dalam pembelajaran. Hasil penelitian menunjukan bahwa siswa-siswa memiliki kesadaran tinggi untuk memanfaatkan e-learning dalam pembelajarannya.

Pembelajaran problem solving menggunakan e-learning juga merupakan salah satu fasilitas yang menggunakan kemajuan IPTEK guna pencapain prestasi siswa yang lebih baik dari yang sebelumnya. Dengan bantuan media yang dapat mendukung proses belajar, siswa akan aktif dan mandiri memikirkan segala kemungkinan dalam menyelesaikan masalah yang ada. Disini siswa akan mulai berfikir secara konfergen dengan banyak alternatif jawaban. Dengan begitu siswa akan mulai berpikir secara kreatif. Siswa yang kreatif rasa keingintauannya besar sehingga cenderung berani, dan berpikir mandiri untuk mencari penyelesaian masalah. Dengan begitu siwa akan antusias dengan media e-learning yang diberikan dan berusaha untuk memahami materi sehingga akan berdampak pada naiknya prestasi belajar mereka.

Sementara komik dipilih sebagai media karena komik dapat dimanfaatkan untuk menunjang tercapainya tujuan pembelajaran. komik adalah suatu bentuk sajian cerita dengan seri gambar yang lucu. Dengan mengemas meteri ikatan kimia dalam komik yang sedang digemari siswa, akan dapat memberi inspirasi siswa untuk bersemangat membaca dan membolak balik komik untuk menyelesaikan masalah. Komik bisa dikatakan sebagai suatu bentuk karya seni yang menggunakan gambargambar tidak bergerak yang disusun sedemikian rupa sehingga membentuk jalinan cerita dari sebuah ide, sehingga walaupun digunakan untuk media pembelajaran perlu daya imajinasi yang tinggi dalam memahami. Siswa yang mempunyai daya kreativitas tinggi biasanya lebih cepat mengerti sebuah karya seni yang dituangkan dalam gambar yang disajikan dengan pemilihan warna yang menarik, dan ini dapat meningkatkan kreativitas siswa. Dalam penelitian ini siswa yang kreativitasnya tinggi lebih baik prestasi belajarnya jika mengunakan media komik. Dengan demikian ada interaksi antara pembelajaran kimia berbasis problem solving menggunakan e-learning dan komik dengan kreativitas terhadap prestasi belajar siswa ranah kognitif, tetapi tidak ada interaksi yang signifikan antara pembelajaran kimia berbasis problem solving menggunakan e-learning dan komik dengan kreativitas siswa ranah afektif.

Interaksi antara kemampuan berpikir abstrak dengan kreativitas dan terhadap prestasi belajar siswa.

Dari hasil uji statistik menyatakan bahwa ada interaksi yang signifikan antara kemampuan berpikir abstrak dengan kreativitas terhadap prestasi belajar siswa ranah kognitif, tetapi tidak ada interaksi yang signifikan antara kemampuan berpikir abstrak dengan kreativitas terhadap prestasi belajar siswa ranah afektif.

Dalam pendapatnya Jacobsen (2010) mengatakan bahwa fungsi abstraksi 
yang membuat bernilai dalam kurikulum adalah kemudahan untuk menggunakannya dalam membuat prediksi masa depan. Di sini berarti siswa yang berpikir abstrak tinggi akan mempunyai daya imajinatif, inovatif dan ulet. Hal tersebut merupakan ciri-ciri siswa yang berpikir kreatif. Dengan demikian siswa yang berpikir abstrak tinggi dengan mempunyai kreativitas tinggi akan meningkat hasil belajarnya. Jadi ada interaksi antara siswa yang berpikir abstrak dengan kreativiatas belajar.

Adanya interaksi yang signifikan antara kemampuan berpikir abstrak dan kreativitas ditinjau dari prestasi belajar aspek kognitif berarti siswa yang memiliki kreativitas tinggi memiliki prestasi belajar aspek kognitif yang lebih tinggi daripada siswa yang memiliki kreativitas rendah apapun kemampuan berpikir abstraknya. Sedangkan untuk siswa yang memiliki kemampuan berpikir abstrak tinggi lebih baik prestasi kognitifnya daripada siswa yang memiliki kemampuan berpikir abstrak rendah baik siswa yang kreativitasnya tinggi dan rendah. Tidak adanya interaksi yang signifikan antara kemampuan berpikir abstrak dan kreativitas ditinjau dari prestasi belajar aspek afektif berarti baik siswa yang memiliki kemampuan berpikir abstrak tinggi maupun rendah tidak memiliki perbedaan prestasi belajar yang signifikan terhadap kreativitas tinggi dan rendah.

Interaksi antara pembelajaran kimia berbasis problem solving menggunakan $e$ learning dan komik, kemampuan berpikir abstrak dan kreativitas terhadap prestasi belajar siswa.

Dari hasil perhitungan statistik menyatakan bahwa ada interaksi yang signifikan antara pembelajaran kimia berbasis problem solving menggunakan $e$ learning dan komik, kemampuan berpikir abstrak, dan kreativitas terhadap prestasi belajar siswa ranah kognitif, tetapi tidak ada interaksi yang signifikan antara pembelajaran kimia berbasis problem solving menggunakan e-learning dan komik, kemampuan berpikir abstrak, dan kreativitas terhadap prestasi belajar siswa ranah afektif. Penggunaan media pembelajaran akan membantu dalam penyampaian materi dari guru ke siswa. Jika tidak tepat dalam pemilihan media dan kondisi siswa yang tidak kooperatif dapat memperlambat jalanya proses pembelajaran. Penggunaan media e-learning dan komik disesuaikan dengan keadaan karakteristik siswa sehingga mampu meningkatkan prestasi belajar siswa. Sifat dan karekteristik anak smk yang masih sulit untuk berkonsentrasi dan tidak serius dalam menerima pelajaran adatif membuat mereka kurang semangat dalam pembelajaran. Dengan pembelajaran mengggunaka $e$ learning dan komik mereka lebih antusias dan mulai menyenangi pelajaran kimia terutama pada materi ikatan kimia.

Penelitian yang dilakukan oleh Somer, dkk (1994) mengembangkan pembelajaran problem solving yang meliputi empat tahapan yaitu clarify (menjelaskan), organize (mengatur), resolve (memutuskan), dan examine the problem (memeriksa masalah). Hasil penelitian ini menunjukkan bahwa model pembelajaran ini meningkatkan kepercayaan siswa dalam pemecahan masalah.

Dalam penelitian ini siswa yang mempunyai kemampuan berpikir abstrak tinggi dan kreativitas tinggi, prestasi belajarnya akan lebih bagus menggunakan media komik dibanding $e$ - learning. Ini dikarenakan siswa tersebut mempunyai daya imajinasi tinggi sehingga lebih cepat untuk memahami materi ikatan yang disajikan dalam komik yang merupakan salah satu bentuk karya seni. Begitu pula siswa yang mempunyai kemampuan berbikir abstrak rendah dan kreativitas rendah akan lebih baik prestasi belajarnya bila digunakan media komik. Hal tersebut berakibat adanya interaksi antara pembelajaran problem solving dengan menggunakam media $e$ learning dan komik ditinjau dari kemampuan berpikir abstrak dan kreativitas siswa. 


\section{Kesimpulan dan Rekomendasi}

Berdasarkan hasil analisis dan pembahasan diperoleh kesimpulan sebagai berikut: 1) ada pengaruh pembelajaran kimia berbasis masalah menggunakan metode proyek dan eksperimen terhadap prestasi belajar kognitif siswa, namun tidak ada pengaruh terhadap prestasi belajar afektif; 2) tidak ada pengaruh kreativitas terhadap prestasi belajar kognitif dan afektif siswa; 3 ) ada pengaruh keterampilan menggunakan alat laboratorium terhadap prestasi belajar kognitif siswa, namun tidak ada pengaruh pada prestasi belajar afektif; 4) tidak ada interaksi antara pembelajaran kimia berbasis masalah menggunakan metode proyek dan eksperimen dengan kreativitas terhadap prestasi belajar kognitif dan afektif siswa; 5) ada interaksi antara pembelajaran kimia berbasis masalah menggunakan metode proyek dan eksperimen dengan keterampilan menggunakan alat laboratorium terhadap prestasi belajar kognitif siswa, namun tidak ada interaksi terhadap prestasi belajar afektif; 6) ada interaksi antara kreativitas dan keterampilan menggunakan alat laboratorium terhadap prestasi kognitif siswa, namun tidak ada interaksi pada prestasi afektif; 7) tidak ada interaksi antara pembelajaran kimia berbasis masalah menggunakan metode proyek dan eksperimen, kreativitas dengan keterampilan menggunakan alat laboratorium terhadap prestasi kognitif dan afektif siswa.

Rekomendasi dari hasil penelitian yang telah dilakukan adalah sebagai berikut: a) pembelajaran yang optimal dapat dilakukan dengan pemilihan pendekatan, strategi, metode, dan media yang sesuai dengan karakteristik materi dan karakteristik siswa. Pembelajaran berbasis problem solving dengan menggunakan media $e$ learning dan komik dapat digunakan sebagai strategi pembelajaran alternatif untuk meningkatkan kualitas pendidikan; b) dalam pembelajaran kimia sebaiknya guru memperhatikan kemampuan berpikir abstrak dan kreativitas siswa, karena sangat berpengaruh terhadap prestasi belajar siswa; c) untuk meningkatkan hasil belajar siswa dilihat dari faktor kemampuan berpikir abstrak siswa, sebaiknya digunakan pembelajaran berbasis problem solving dengan media e-learning untuk siswa yang memiliki kemampuan berpikir abstrak rendah. Sedangkan untuk siswa yang memiliki kreativias rendah sebaiknya digunakan pembelajaran problem solving dengan media komik.

\section{Daftar Rujukan}

Aunurrahman. (2006). Belajar dan Pembelajaran. Bandung: Alfabeta.

Chang, R. (2005). Kimia Dasar Konsep-Konsep Inti. Penerjemah: Suminar Setiati Achmadi. Jakarta: Erlangga.

Dahar RW. (1989). Teori-Teori Belajar. Jakarta: Erlangga.

-----------. (2006). Teori-Teori Belajar. Jakarta: Erlangga.

Daryanto. (2010). Media Pembelajaran. Yogyakarta: Gava Media

Depdiknas. (2003). Pengembangan perangkat Penilaian Afektif. Dirjen Pendidikan Dasar dan Menengah. Jakarta (Unpublised)

Jacobsen. David A . EggenP. Kauchak D. (2009). Methods for Teaching. Penerjemah: Achmad Fawaid dan Khoirul Anam. Yogyakarta: Pustaka Pelajar.

Mulyasa E. (2010). Implementasi Kurikulum Tingkat Satuan Pendidikan. Jakarta: Bumi Aksara.

Munandar U. (2009). Pengembangan Kreativitas Anak Berbakat. Jakarta: Rineka Cipta.

Munadi Y. (2010). Media Pembelajaran Sebuah Pendekatan Baru. Jakarta: GP Press.

Sanjaya W. (2010). Strategi Pembelajaran Berorientasi Standar Proses Pendidikan. Jakarta: Prenada Media Group.

Somers, K. dkk. (1994). CORE: An Interdiciplinary Course In Quantitative Problem Solving. PRIMUS, 4:1, 55-69. 
JURNAL INKUIRI

ISSN: 2252-7893, Vol 2, No 32013 (hal 288-301)

http://jurnal.fkip.uns.ac.id/index.php/sains

Suyono. (2010). Belajar dan Pembelajaran. Bandung: Rosdakarya

Winkel, W.S. (2009). Psikologi Pengajaran. Yogyakarta: Media Abadi.

Talatovic, M. (2009). Science comics as tool for science education and communication: a brief, exploratory study. Journal off Science Communication, 1-15.

Yacob A. dkk (2011). Student awarness towards e-learning in education. Procedia ,9310 .

Winataputra U.S, dkk. (2007). Teori Belajar dan Pembelajaran. Jakarta: Universitas Terbuka. 